\title{
Risk of Alcohol Abuse in Humans with Attention- deficit/Hyperactivity Disorder Symptoms
}

\author{
Annapurna Kuppa ${ }^{1}$, Areeba Maysun ${ }^{2}$ \\ 1. Internal Medicine and Gastroenterology, University of Michigan, Ann Arbor, USA 2. Neurology, University of \\ Michigan, Ann Arbor, USA
}

Corresponding author: Annapurna Kuppa, annapurnakuppa1@gmail.com

\begin{abstract}
The relationship between attention-deficit/hyperactivity disorder (ADHD) and the risk of alcohol abuse is widely studied. Even though this topic has been of interest for several years, it is heavily debated. We studied various papers and conducted a systematic review using PubMed as the main source of data collection. We found that several studies put forward the concept of a positive association between alcohol abuse and ADHD symptoms, but a minority of them also showed opposing and contradictory results. We discovered that this inconsistency observed in studies could be a result of a biased approach in studies and a subjective attempt in interpretations. These biases could be studied in terms of sample size involved in the analysis, age at which studies are conducted among other statistical parameters. We believe that the deviations in the outcomes prove that the studies may be incomplete and that a standardized method of interpretation is required. Therefore, this paper recommends the need for further research to explore the connection between alcohol abuse in patients showing ADHD symptoms.
\end{abstract}

Categories: Neurology, Psychology

Keywords: adhd, adhd alcohol, attention alcohol, adhd drug abuse, adhd drinking, hyperactivity alcohol

\section{Introduction And Background}

Coming across kids with aggressive and defiant behavior is not very uncommon, especially when observed in specific situations. These kids face issues in doing simple and normal things like completing homework, eating, or going to bed and are victims of a mental disorder [1]. This reflects the agony of patients suffering from attention-deficit/hyperactivity disorder (ADHD). Recent studies have shown that ADHD can stretch beyond puberty and into adulthood [2], thus the steps that a patient is willing to take could be beyond our imagination, possibly including alcohol abuse.

Received 10/04/2019

Review began 10/13/2019 Review ended 10/23/2019 Published 10/25/2019

\section{๑) Copyright 2019}

Kuppa et al. This is an open access article distributed under the terms of the Creative Commons Attribution License CC-BY 3.0., which permits unrestricted use, distribution, and reproduction in any medium, provided the original author and source are credited.
American Psychiatric Association (2014) reveals that about 5\% of children have been diagnosed with ADHD [3]. Even though there has been a lot of research published on ADHD, we are still struggling to understand it completely. There have been reports that indicate that about $2 \%-8 \%$ of ADHD patients are enrolled in a university and that about $37 \%-60 \%$ of the students are heavy drinkers [4]. Thus, it is important to study the risk of alcohol abuse in ADHD patients. Alcohol consumption can be associated with two motives, either to have fun, i.e. positively reinforcing, or to forget about problems, i.e. negatively reinforcing. Poor impulse control, emotional imbalance, problems delaying gratification, and increased sensitivity for immediate returns may lead to heavy drinking in patients suffering from ADHD [5].

There have been multiple reports published on the correlation between alcohol abuse and ADHD [4]. Alcohol misuse was found to be more frequent in people who were diagnosed with ADHD at the childhood stage [6] and the misuse can also lead to some personality changes [7]. Brinkman et al. showed that the starting age for alcohol consumption is lower for adolescents suffering from ADHD as opposed to healthy individuals [8]. Another study revealed contradictory results, which stated that the extent of alcohol abuse was less likely in students suffering from ADHD [9]. Thus, a need arises to understand the correlation between alcohol abuse and ADHD patients and its impact across their lifespan.

In this paper, we will proclaim the importance of studying alcohol abuse and its risk in ADHD patients. We start by describing and enlisting various studies in the past five years from PubMed publications. The discussion delves into studying two sides of the coin, i.e. one where the risk of alcohol abuse is positively correlated with ADHD symptoms and the other where there is no association between the two. The results section gives us insights into 29 publications and highlights the important aspects and significance of their study. The review concludes by visually representing the discrepancies in the studies in terms of sample size. The paper will also briefly touch upon the importance of parental interference in delaying the risk of alcohol abuse.

\section{Review}

This systematic review reports the association between patients suffering from ADHD and the risk of alcohol 
abuse. Since PubMed is a repository of many publications [9], it was chosen to be the main source for conducting reviews on ADHD and alcohol abuse. Cross-checking during data evaluation helped in the documentation of additional relevant references. Proactive discussions between the authors helped in assessing the inclusion and exclusion criteria of the publications. Articles with patient data were incorporated. Data were collected from papers published in the last five years (2013-2018). Records covering the risk of alcohol abuse in patients diagnosed with ADHD were thoroughly reviewed, and articles focusing on this association were incorporated. Studies from low-impact journals were excluded to preserve the high standard of this review. A total of 16,913 publications were retrieved using the following keywords: ADHD, ADHD alcohol, attention alcohol, ADHD alcohol abuse, ADHD drinking, and hyperactivity alcohol. After review, 49 articles were included based on their significance to ADHD and its association with alcohol abuse.

\section{Results}

Table 1 lists various studies indicating an interdependence between the risk of alcohol use and ADHD patients [4,8,10-29]. Several studies have reported that ADHD and alcohol abuse have a direct positive correlation [30-41]. Nevertheless, there have been many contradictory reports showing that the risk of alcohol abuse does not depend on ADHD [4, 42-44]. Another study shows that inattention may be an important factor contributing to alcohol abuse but not hyperactivity. Multiple reports showing multiple results (as seen in Table 1) can lead to higher confusion in the interpretation of ADHD symptoms and their association with alcohol binge use. Some of the studies have been conducted more thoroughly, with higher sample size, whereas others have been conducted with better statistical interpretation. Some of the contradictory studies with a sub-optimal sample size could cloud our judgment and lead to potential bias in our understanding.

\begin{tabular}{|c|c|c|c|c|c|}
\hline Study & $\begin{array}{l}\text { Publication } \\
\text { Year }\end{array}$ & $\begin{array}{l}\text { Location of } \\
\text { study }\end{array}$ & Sample size & $\begin{array}{l}\text { Study Design/ } \\
\text { Methodology }\end{array}$ & Main findings \\
\hline $\begin{array}{l}\text { Heradstveit } \\
\text { et al. [34] }\end{array}$ & 2019 & Norwegian & $N=9,408$ & $\begin{array}{l}\text { Ages } 16 \text { - } 19 . \\
\text { Questionnaire-based } \\
\text { study }\end{array}$ & $\begin{array}{l}\text { They found that several comorbid } \\
\text { factors and psychiatric disorders are } \\
\text { possibly involved in linking ADHD to } \\
\text { drug abuse and recommend } \\
\text { additional studies for their } \\
\text { susceptibility to alcohol misuse. }\end{array}$ \\
\hline $\begin{array}{l}\text { llbegi et al. } \\
\text { [35] }\end{array}$ & 2018 & Dutch & $\begin{array}{l}\text { The population was } \\
\text { distributed as } 62 \text { with } \\
\text { persistent ADHD, } 12 \\
\text { with remittent, } 18 \text { with } \\
\text { ADHD detected after } \\
\text { the age of } 12,50 \\
\text { siblings who are not } \\
\text { affected with ADHD } \\
\text { and } 47 \text { healthy } \\
\text { controls. }\end{array}$ & $\begin{array}{l}\text { The study was started at } \\
\text { the average age of } 11.3 \\
\text { and the average age at } \\
\text { follow-up was } 21.1\end{array}$ & $\begin{array}{l}\text { Those suffering from persistent ADHD } \\
\text { and affected siblings with delayed } \\
\text { ADHD detection are affected by } \\
\text { alcohol abuse at a higher rate } \\
\text { compared to controls. This trend was } \\
\text { not observed in remittent ADHD } \\
\text { patients. }\end{array}$ \\
\hline $\begin{array}{l}\text { Jo et al. } \\
\text { [36] }\end{array}$ & 2018 & Korea & $\begin{array}{l}62 \text { males affected with } \\
\text { an alcohol use disorder }\end{array}$ & $\begin{array}{l}\text { Adults were employed in } \\
\text { this study }\end{array}$ & $\begin{array}{l}\text { The severity of ADHD in childhood } \\
\text { depends on the addiction to alcohol } \\
\text { and its use disorder in adulthood. }\end{array}$ \\
\hline $\begin{array}{l}\text { Grant et al. } \\
\text { [17] }\end{array}$ & 2018 & UK & $\begin{array}{l}3421 \text { students from } \\
\text { Universities }\end{array}$ & $\begin{array}{l}\text { Questionnaire-based } \\
\text { anonymous survey }\end{array}$ & $\begin{array}{l}\text { Non-medical usage of prescription } \\
\text { drugs was found in } 6.7 \% \text { of the } \\
\text { population. The link between ADHD } \\
\text { and the use of non-medical } \\
\text { prescription stimulants was not } \\
\text { evident. }\end{array}$ \\
\hline $\begin{array}{l}\text { Jacob et al. } \\
\text { [37] }\end{array}$ & 2018 & UK & 7403 & $\begin{array}{l}\text { More than } 16 \text { years of } \\
\text { age }\end{array}$ & $\begin{array}{l}\text { Dependence on alcohol increases the } \\
\text { susceptibility of ADHD patients to } \\
\text { gambling problems. }\end{array}$ \\
\hline $\begin{array}{l}\text { Romo et al. } \\
\text { [38] }\end{array}$ & 2018 & France & $\begin{array}{l}1517 \text { student } \\
\text { population }\end{array}$ & $\begin{array}{l}\text { Questionnaire-based } \\
\text { survey. } 20.6 \text { years was } \\
\text { the mean age of } \\
\text { subjects }\end{array}$ & $\begin{array}{l}\text { Higher alcohol scores were found in } \\
\text { students suffering from ADHD than } \\
\text { the controls. }\end{array}$ \\
\hline $\begin{array}{l}\text { Du et al. } \\
\text { [39] }\end{array}$ & 2018 & UK & $\begin{array}{l}20,183 \text { samples from } \\
\text { UK Biobank with } 35,191 \\
\text { cases of control }\end{array}$ & $\begin{array}{l}\text { Genome-wide } \\
\text { association studies }\end{array}$ & $\begin{array}{l}\text { Patients that have many risk alleles } \\
\text { that are known to cause ADHD are } \\
\text { also shown to be at a higher risk of }\end{array}$ \\
\hline
\end{tabular}




\section{Cureus}

\begin{tabular}{|c|c|c|c|c|c|}
\hline & & & & & alcohol dependence. \\
\hline $\begin{array}{l}\text { Patel et al. } \\
\text { [23] }\end{array}$ & 2018 & USA & 11,232 ADHD patients & $\begin{array}{l}\text { Binomial logistic } \\
\text { regression model }\end{array}$ & $\begin{array}{l}\text { Risk of cannabis use disorder is } \\
\text { higher in males with ADHD }\end{array}$ \\
\hline $\begin{array}{l}\text { Jaisoorya } \\
\text { et al. [40] }\end{array}$ & 2017 & India & $\begin{array}{l}5784 \text { students from } 58 \\
\text { colleges. }\end{array}$ & $\begin{array}{l}\text { Stratified Random } \\
\text { sampling }\end{array}$ & $\begin{array}{l}\text { The study classified students into two } \\
\text { groups: low-risk and high-risk alcohol } \\
\text { users. They concluded that students } \\
\text { showing high-risk behavior have } \\
\text { higher chances of picking-up part- } \\
\text { time/temporary jobs, ADHD } \\
\text { symptoms, and more prone to } \\
\text { tobacco use as opposed to their low- } \\
\text { risk counterparts. }\end{array}$ \\
\hline $\begin{array}{l}\text { Howard et } \\
\text { al. [4] }\end{array}$ & 2017 & Canada & $\begin{array}{l}\text { Students out of which } \\
31 \text { are suffering from } \\
\text { ADHD and } 146 \text { as the } \\
\text { control population. }\end{array}$ & $\begin{array}{l}\text { The study involved } \\
\text { completing an online } \\
\text { questionnaire and fitting } \\
\text { logistic regression } \\
\text { models. }\end{array}$ & $\begin{array}{l}\text { This study showed that there is no } \\
\text { correlation between ADHD and the } \\
\text { risk of alcohol use. In fact, they } \\
\text { concluded that the control population } \\
\text { abused heavy drinking } 1.44 \text { times } \\
\text { more than those with ADHD. }\end{array}$ \\
\hline $\begin{array}{l}\text { King et al. } \\
\text { [20] }\end{array}$ & 2017 & USA & 259 individuals & $14-17$ years & $\begin{array}{l}\text { This study indicated that intervention } \\
\text { is necessary to moderate alcohol } \\
\text { abuse. ADHD symptoms also showed } \\
\text { a higher association with life events } \\
\text { that are negatively perceived as well } \\
\text { as more alcohol abuse at } 17 \text { years of } \\
\text { age. }\end{array}$ \\
\hline $\begin{array}{l}\text { Connolly et } \\
\text { al. [41] }\end{array}$ & 2016 & Canada & $\mathrm{N}=17,311$ adults & $\begin{array}{l}2012 \text { Canadian } \\
\text { Community Health } \\
\text { Survey data that was } \\
\text { available publicly. }\end{array}$ & $\begin{array}{l}\text { The study found that Canadian adults } \\
\text { who self-reported an ADHD diagnosis } \\
\text { were exposed to a higher risk of } \\
\text { alcohol drinking, smoking, and other } \\
\text { substance use. }\end{array}$ \\
\hline $\begin{array}{l}\text { Vogel et al. } \\
{[18]}\end{array}$ & 2016 & Swiss & $\begin{array}{l}5103 \text { males with a } \\
\text { mean age of } 20 .\end{array}$ & $\begin{array}{l}\text { Longitudinal Cohort } \\
\text { Study. }\end{array}$ & $\begin{array}{l}\text { The study found that ADHD can lead } \\
\text { to the continuous use of alcohol, } \\
\text { tobacco, and cannabis as compared } \\
\text { to control. ADHD group did not show } \\
\text { an increase in use when they are } \\
\text { already consuming these products. }\end{array}$ \\
\hline $\begin{array}{l}\text { Selinus et } \\
\text { al. [25] }\end{array}$ & 2016 & Swedish & 4635 & $\begin{array}{l}\text { Ages } 9 \text { or } 12 . \\
\text { Questionnaire }\end{array}$ & $\begin{array}{l}\text { The study concluded that alcohol } \\
\text { abuse is associated with ADHD } \\
\text { symptoms and is more common in } \\
\text { girls than in boys. }\end{array}$ \\
\hline $\begin{array}{l}\text { Squeglia et } \\
\text { al. [21] }\end{array}$ & 2016 & USA & 139 Parents & $\begin{array}{l}\text { Parents of children } \\
\text { between } 6-9 \text { years with } \\
77 \text { in the ADHD group } \\
\text { and } 62 \text { without ADHD. }\end{array}$ & $\begin{array}{l}\text { The study found that childhood ADHD } \\
\text { symptoms predicted expectancies } \\
\text { involving alcohol-arousing property. }\end{array}$ \\
\hline $\begin{array}{l}\text { Quinn et al. } \\
{[19]}\end{array}$ & 2016 & Swedish & $\begin{array}{l}15,549 \text { individuals with } \\
\text { childhood detection of } \\
\text { ADHD and } 2564 \\
\text { individuals in late } \\
\text { adolescence with } \\
\text { alcohol problems. }\end{array}$ & $\begin{array}{l}\text { Ages } 9 / 12 \text { and } 18 \text {. } \\
\text { longitudinal, population- } \\
\text { based study }\end{array}$ & $\begin{array}{l}\text { The study found that ADHD } \\
\text { symptoms did lead to higher alcohol- } \\
\text { related problems, but the magnitude } \\
\text { of the difference was not large. }\end{array}$ \\
\hline $\begin{array}{l}\text { Kolla et al. } \\
\text { [22] }\end{array}$ & 2016 & Canada & 5080 & $\begin{array}{l}\text { Age 18. cross-sectional } \\
\text { telephone survey }\end{array}$ & $\begin{array}{l}\text { The study found that the expression } \\
\text { of ADHD symptoms is caused by } \\
\text { improper alcohol and cannabis abuse. } \\
\text { There might also be substance abuse } \\
\text { based on gender. }\end{array}$ \\
\hline $\begin{array}{l}\text { Tong et al. } \\
\text { [24] }\end{array}$ & 2016 & China & 1870 students & Cross-sectional study & $\begin{array}{l}\text { The study showed that inattention } \\
\text { and hyperactivity both lead to higher } \\
\text { depression and anxiety risk, which in } \\
\text { turn caused increased smoking and }\end{array}$ \\
\hline
\end{tabular}




\section{Cureus}

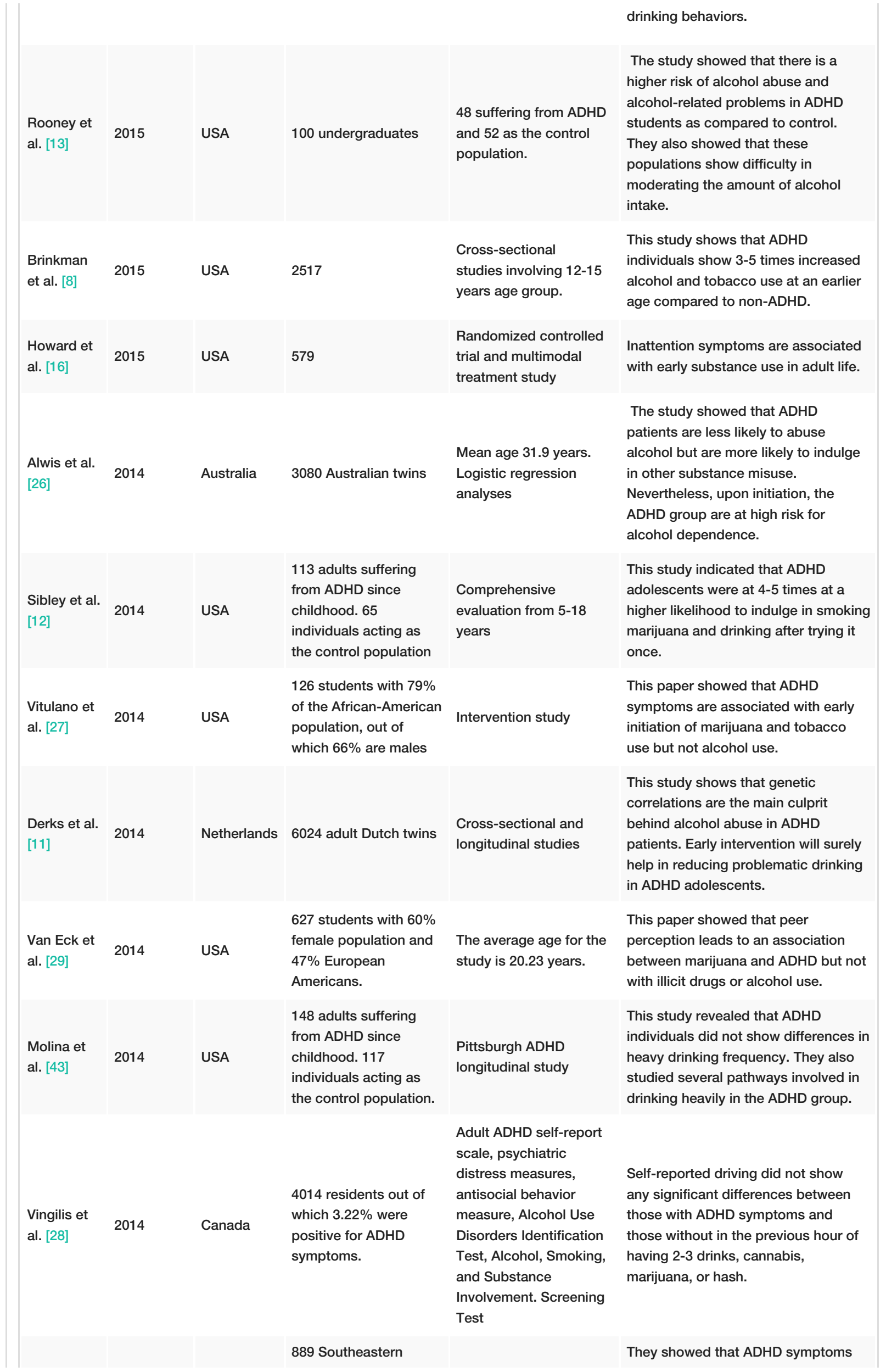




\section{Cureus}

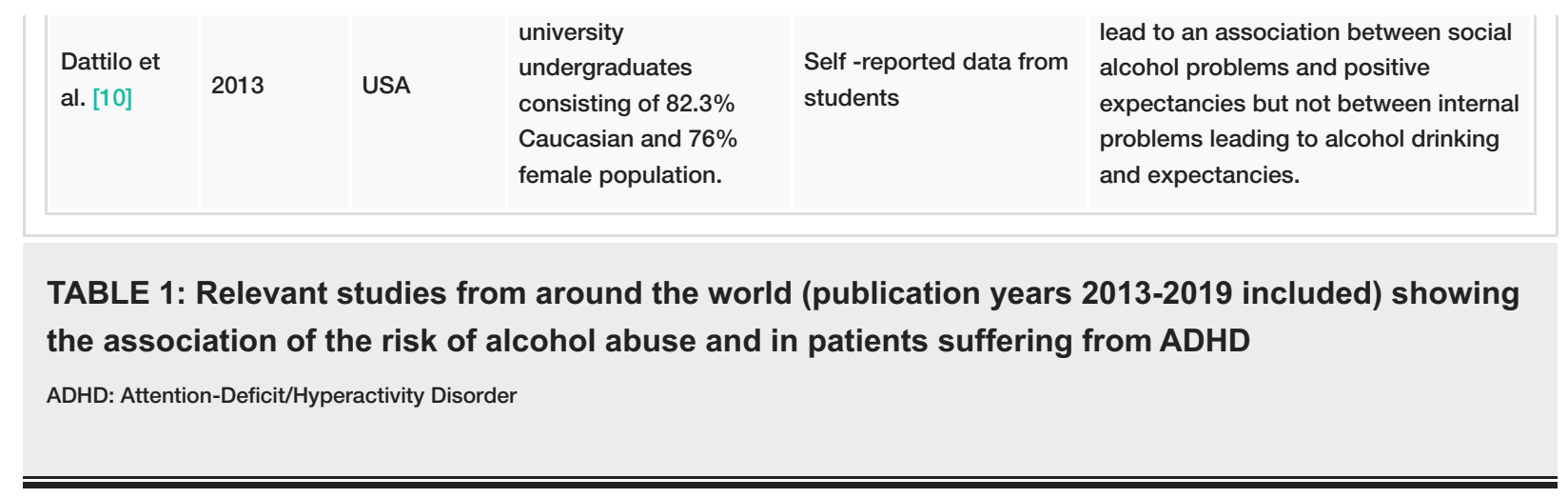

Selinus et al., 2016, performed a gender-based study of 4635 individuals and their connection with alcohol abuse [25]. They found that females are more prone to alcohol misuse than males. Even though the sample size for this study was 4635 , there might be certain parameters that may not have been considered, for example, correlating alcohol drinking at a very young age (9-12 years). There are numerous results that do not seem to agree on the outcomes and, thus, we need to study more to provide a better conclusive report on the association of alcohol abuse in patients suffering from ADHD. In-silico studies [45] may be performed for tricky cases to understand behavioral responses to alcohol.

Discussion

ADHD is a chronic disorder that persists from childhood to adulthood in many patients [11]. Owing to several cognitive and behavioral difficulties [11], such individuals are at a higher risk for alcohol abuse [12]. Thus, it is important to explore the motives for heavy alcohol drinking in ADHD affected patients.

\section{ADHD Leads to Alcohol Abuse}

Many studies have shown that a connection between childhood ADHD and alcohol abuse is common (see Table 1). Jaisooya et al., 2017, conducted a study on 5784 students and concluded that those students who reported high risk for alcohol use showed ADHD symptoms [40]. People who self-reported with ADHD showed a higher likelihood of alcohol abuse [41]. A study was performed on 6024 adult Dutch twins by Derks et al., 2014, which convincingly showed that problem drinking and ADHD symptoms are related in adults [11]. Affiliation can be found between ADHD childhood and deviant peers, which, in turn, causes the former to mediate alcohol abuse as teens. A total of 889 undergraduates (59\% reported ADHD) participated in a study that indicated that ADHD symptoms moderated the association between alcohol problems and the expected beliefs from alcohol use [10]. Individuals detected with ADHD symptoms are also involved in binge drinking. Sibley et al., 2014, performed a study where childhood ADHD patients were followed and tracked until 18 years of age [12]. This study revealed that adolescents with ADHD start drinking at an early age as opposed to their peers. Multiple studies have also shown that ADHD suffering students have an increased rate of alcohol-use disorders and problems. The struggle in stopping the amount of alcohol intake during a drinking session can act as a mechanism for alcohol abuse among students with ADHD [13].

\section{ADHD Does Not Lead to Alcohol Abuse}

There have been several contradictory studies published that show that alcohol abuse and ADHD are not associated (see Table 1). Even though there have been multiple studies showing their association, we should not overlook the fact that some parameters might have been left unturned or not taken into consideration. Sibley et al., 2014, revealed such a parameter [12]. Their study involved tests that showed that, generally, alcohol use assessment is performed at 14 years but, usually, non-ADHD diagnosed teens do not initiate drinking before attaining 15 years. Thus, we cannot rule out the possibility that a mismatched interpretation might be occurring because of the observation being performed at the wrong time.

The relative lack of research in the field and limitations of the existing studies may lead to problems at a later stage. Thus, interventions at an early stage are needed to prevent ADHD affected individuals from developing a drinking problem [12]. Some studies have also shown that parental influence can help in monitoring the risk of alcohol abuse in ADHD adolescents [46]. There is also a study that focuses on the drinking behavior of parents that are raising kids with ADHD [14]. The tendency for alcohol abuse can be observed not only in ADHD patients but also in the parents nurturing them. Thus, there is a higher need to study the association between ADHD and the risk of alcohol abuse.

Even though there are multiple contradictory reports, those in favor of the higher risk of alcohol abuse in ADHD adolescents were found to be greater. Furthermore, an association has also been indicated between alcohol and substance abuse and the risk of criminal behavior in ADHD [15]. Due to the lack of recovery of motor control [47] in patients suffering from ADHD as compared to non-ADHD, the risk of driving under 
alcohol influence also increases [48]. A thorough study is needed to evaluate and determine the differences between the ADHD and non-ADHD groups.

This paper helps to bring out the controversies in reports of ADHD symptoms and its association with alcohol abuse. Several studies have shown results where some say that alcohol and ADHD are correlated but they are also strongly opposed by other studies that indicate that there is no association. Some publications also reveal that inattention is correlated but hyperactivity is not. It appears that certain different parameters have been studied in these papers. As the paper by Roberts et al., 2013, suggests, the blood alcohol concentration may have been studied in the ascending limb but not in the descending limb [48]. This could have resulted in a biased outcome of the study. The age at which the alcohol initiation studies have been conducted can also impair the results from a study. Also, the discrepancies in the study as a function of sample size may have resulted in a skewed interpretation of the outcome (see Figure 1). It is sad to see that several studies show extremely tender-aged individuals, especially between 11 and 17 years of age, to be candidates of high-risk alcohol abuse. From study to study, a significant consideration is the difference in sample sizes because such size variety can affect the results and conclusions made. For example, a study conducted by Grabemann et al. recommends larger sample sizes in future studies for diagnosing ADHD based on the results of their study with a total size of 102 patients [49]. Nonetheless, an association study suggests larger observational studies in the future even though their study consists of 135,726 participants [39]. Therefore, there is not a universal sample size for all studies, and it depends on the ADHD literature as seen. Selection bias can result from inaccurately collecting study samples. Thus, when analyzing several papers with small sample sizes, it is important to utilize a meta-analysis with caution. This paper emphasizes the need for a more standardized approach for studying the risk of alcohol abuse in ADHD patients. This paper also exclaims on the importance of taking several precautions and routes to reduce the dependency of ADHD patients on alcohol and other substance use (see Figure 2). Prenatal alcohol exposure (PAE) is shown to have many detrimental effects on the child in many ways. Nevertheless, the consequences of prenatal alcohol exposure are not shown until later in child development. There have been reports that showed that having a parental influence and interference at the right time can decrease the susceptibility of $\mathrm{ADHD}$ patients on alcohol. Also, some other studies prove that the risk for alcohol abuse can be lowered by delaying the initiation of alcohol misuse.

\section{Sample size of the patients involved in each study conducted over the past 5 years}

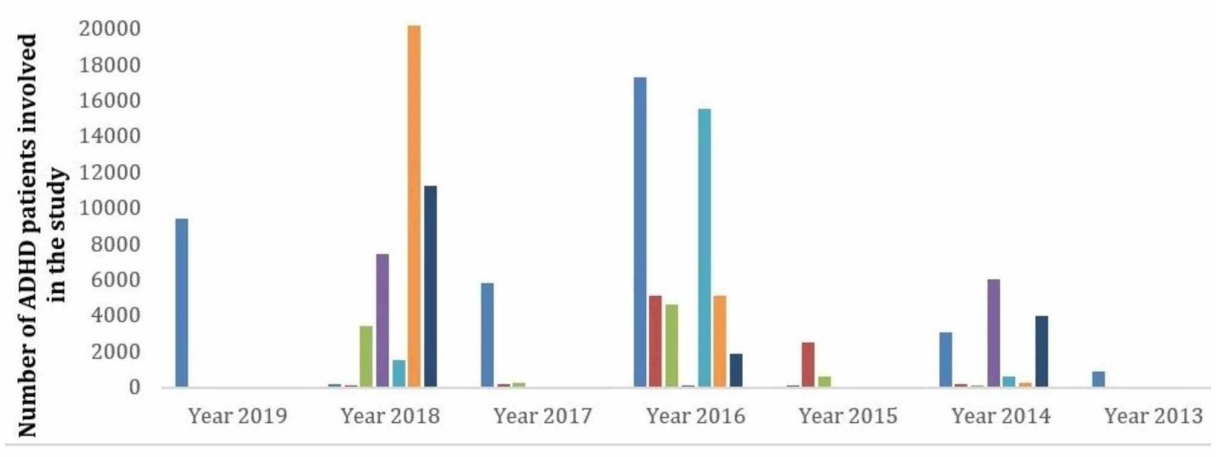

FIGURE 1: The bar graph above shows the relation between the number of individuals employed in the study vs the year of various publications

It can be clearly seen that the outcomes may have been altered by the sample size. Some studies have a higher sample size of 17311 while others have a sample size as low as 40 . 


\section{Cureus}

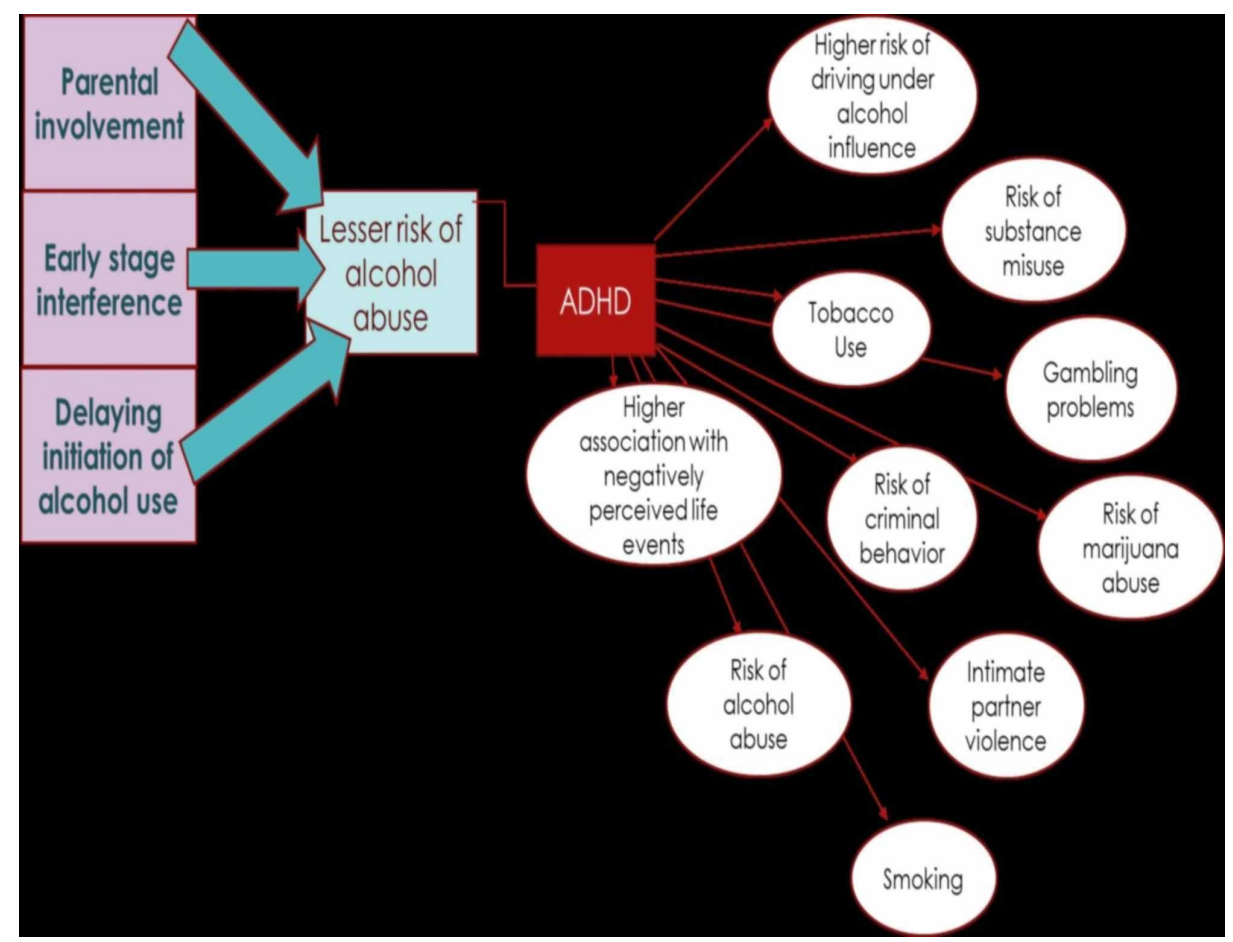

FIGURE 2: The picture shows the relation between ADHD and the risks associated

It also reflects how alcohol abuse can be lowered in patients diagnosed with ADHD symptoms: involvement of a parent at the right age, interfering with the abuse early on, and by procrastinating the start of alcohol consumption.

This paper interjects and contributes to the understanding of the higher alcohol abuse risk in the ADHD group of patients. However, further assessment is required in the interpretation of the association due to some limitations. First, the reports included publications from PubMed. Other sources for data inclusion were not considered. Second, a five-year limit (2013-2018) was used for data collection. Third, our data collection is small and limited. Fourth, we did not include any animal studies in the scope of this paper. Additional data integration can help in limiting a certain bias of the studies included in this paper. Thus, there is a need for conducting and evaluating further studies involving the risk of alcohol abuse in ADHD patients, especially the ones that divulge into the mechanisms of alcohol-related problems [13,27].

\section{Conclusions}

This paper has helped bring out numerous controversies in reports of ADHD symptoms and its association with alcohol abuse. Our review helps in the identification of various studies that claim that alcohol and $\mathrm{ADHD}$ are correlated, and many others that strongly oppose and indicate that there is no association between them. We discovered that the age at which the alcohol initiation is studied, especially in children detected with ADHD between 11 and 17 years of age, is incorrect, as some ADHD patients do not even start drinking alcohol by this tender age. We also found that the discrepancies in the study as a function of the sample size could result in a skewed interpretation of the outcome. When and where (ascending or descending limb) the blood alcohol concentration is measured also affects the outcome association of the risk of alcohol abuse and ADHD. This paper emphasizes the need for a more standardized approach for studying the risk of alcohol abuse in ADHD patients.

\section{Additional Information}

\section{Disclosures}

Conflicts of interest: In compliance with the ICMJE uniform disclosure form, all authors declare the following: Payment/services info: All authors have declared that no financial support was received from any organization for the submitted work. Financial relationships: All authors have declared that they have no financial relationships at present or within the previous three years with any organizations that might have an interest in the submitted work. Other relationships: All authors have declared that there are no other relationships or activities that could appear to have influenced the submitted work.

\section{Acknowledgements}


We would like to thank Dr. Hassaan Tohid for acting as our mentor and for his valuable suggestions during the course of this article.

\section{References}

1. Greydanus DE, Pratt HD, Patel DR: Attention deficit hyperactivity disorder across the lifespan: the child, adolescent, and adult. Disease-a-Month. 2007, 53:70-131. 10.1016/j.disamonth.2007.01.001

2. Brook JS, Brook DW, Zhang C, Seltzer N, Finch SJ: Adolescent ADHD and adult physical and mental health, work performance and financial stress. Pediatrics. 2013, 131:5-13. 10.1542/peds.2012-1725

3. Diagnostic and Statistical Manual of Mental Disorders, fifth edition: DSM-5 . American Psychiatric Association, Washington; 2013.

4. Howard AL, Pritchard TR: Heavy drinking in university students with and without attentiondeficit/hyperactivity disorder: contributions of drinking motives and protective behavioral strategies. Subst Abuse. 2017, 11:1-10. 10.1177/1178221817723318

5. Merrill JE, Wardell JD, Read JP: Drinking motives in the prospective prediction of unique alcohol-related consequences in college students. J Stud Alcohol Drugs. 2014, 75(1):93-102.

6. Charach A, Yeung E, Climans T, Lillie E: Childhood attention-deficit/hyperactivity disorder and future substance use disorders: comparative meta-analyses. J Am Acad Child Adolesc Psychiatry. 2011, 50:9-21. 10.1016/j.jaac.2010.09.019

7. Rehan MA, Kuppa A, Ahuja A, et al.: A strange case of dissociative identity disorder: are there any triggers? . Cureus. 2018, 10:e2957. 10.7759/cureus.2957

8. Brinkman WB, Epstein JN, Auinger P, Tamma L, Froehlich TE: Association of attention-deficit/hyperactivity disorder and conduct disorder with early tobacco and alcohol use. Drug Alcohol Depend. 2015, 147:183-189. 10.1016/j.drugalcdep.2014.11.018

9. Janusis GM, Weyandt LL: An exploratory study of substance use and misuse among college students with and without ADHD and other disabilities. J Atten Disord. 2010, 14:205-215. 10.1177/1087054710367600

10. Dattilo L, Murphy KG, Van Eck K, Flory K: Do ADHD symptoms moderate the relation between positive alcohol expectancies and alcohol-related outcomes?. Atten Defic Hyperact Disord. 2013, 5:93-104. 10.1007/s12402-012-0098-y

11. Derks EM, Vink JM, Willemsen G, van den Brink W, Boomsma DI: Genetic and environmental influences on the relationship between adult ADHD symptoms and self-reported problem drinking in 6024 Dutch twins. Psychol Med. 2014, 44:2673-2683. 10.1017/S0033291714000361

12. Sibley MH, Pelham WE Jr, Molina BSG, et al.: The role of early childhood ADHD and subsequent CD in the initiation and escalation of adolescent cigarette, alcohol, and marijuana use. J Abnorm Psychol. 2014, 123:362-374. 10.1037/a0036585

13. Rooney M, Chronis-Tuscano AM, Huggins S: Disinhibition mediates the relationship between ADHD and problematic alcohol use in college students. J Atten Disord. 2015, 19:313-327. 10.1177/1087054712459885

14. Kashdan TB, Adams LM, Kleiman EM, Pelham WE, Lang AR: Stress-induced drinking in parents of boys with attention-deficit-hyperactivity disorder: heterogeneous groups in an experimental study of adult-child interactions. J Abnorm Child Psychol. 2013, 41:919-927. 10.1007/s10802-013-9735-y

15. Knecht C, de Alvaro R, Martinez-Raga J, Balanza-Martinez V: Attention-deficit hyperactivity disorder (ADHD), substance use disorders, and criminality: a difficult problem with complex solutions. Int. J Adolesc Med Health. 2015, 27:163-175. 10.1515/ijamh-2015-5007

16. Howard AL, Molina BSG, Swanson JM, et al.: Developmental progression to early adult binge drinking and marijuana use from worsening versus stable trajectories of adolescent ADHD and delinquency. Addiction. 2015, 110:784-795. 10.1111/add.12880

17. Grant JE, Redden SA, Lust K, Chamberlain S: Nonmedical use of stimulants is associated with riskier sexual practices and other forms of impulsivity. J Addict Med. 2018, 12:474-480. 10.1097/ADM.0000000000000448

18. Vogel T, Dom G, van de Glind G, Studer J, Gmel G, Strik W, Moggi F: Is attention deficit/hyperactivity disorder among men associated with initiation or escalation of substance use at 15-month follow-up? A longitudinal study involving young Swiss men. Addiction. 2016, 111:1867-1878. 10.1111/add.13422

19. Quinn PD, Pettersson E, Lundström S, et al.: Childhood attention-deficit/hyperactivity disorder symptoms and the development of adolescent alcohol problems: a prospective, population-based study of Swedish twins. Am J Med Genet B Neuropsychiatr Genet. 2016, 171:958-970. 10.1002/ajmg.b.32412

20. King KM, Pedersen SL, Louie KT, Pelham Jr., Molina WE, Brooke SG: Between and within person associations between negative life events and alcohol outcomes in adolescents with ADHD. Psychol Addict Behav. 2017, 31:699-711. 10.1037/adb0000295

21. Squeglia LM, Brammer WA, Ray LA, Lee SS: Attention deficit/hyperactivity disorder (ADHD) symptoms predict alcohol expectancy development. J Child Adolesc Subst Abuse. 2016, 25:159-179. 10.1080/1067828X.2014.969856

22. Kolla NJ, van der Maas M, Toplak ME, Erickson PG, Mann RE, Seeley J, Vingilis E: Adult attention deficit hyperactivity disorder symptom profiles and concurrent problems with alcohol and cannabis: sex differences in a representative, population survey. BMC Psychiatry. 2016, 16:50. 10.1186/s12888-016-0746-4

23. Patel RS, Patel P, Shah K, Ravat V, Gudipalli R, Patel V, Patel J: Is cannabis use associated with the worst inpatient outcomes in attention deficit hyperactivity disorder adolescents?. Cureus. 2018, 10:e2033. 10.7759/cureus.3241

24. Tong L, Shi HJ, Zhang Z, Xia ZJ, Jiang XX, Xiong X: Mediating effect of anxiety and depression on the relationship between attention-deficit/hyperactivity disorder symptoms and smoking/drinking. Sci Rep. 2016, 6:21609. 10.1038/srep21609

25. Selinus EN, Molero Y, Lichtenstein P, Anckarsäter H, Lundström S, Bottai M, Gumpert CH: Subthreshold and threshold attention deficit hyperactivity disorder symptoms in childhood: psychosocial outcomes in adolescence in boys and girls. Acta Psychiatr Scand. 2016, 134:533-545. 10.1111/acps.12655

26. Alwis DD, Agrawal A, Reiersen AM, Constantino JN, Henders A, Martin NG, Michael T Lynskey MT: ADHD symptoms, autistic traits, and substance use and misuse in adult Australian twins. J Stud Alcohol Drugs. 
2014, 75:211-221

27. Vitulano ML, Fite PJ, Hopko DR, Lochman, Wells J, Asif K: Evaluation of underlying mechanisms in the link between childhood ADHD symptoms and risk for early initiation of substance use. Psychol Addict Behav. 2014, 28:816-827.

28. Vingilis E, Mann RE, Erickson P, Toplak M, Kolla NJ, Seeley J, Jain U: Attention deficit hyperactivity disorder, other mental health problems, substance use, and driving: examination of a population-based, representative Canadian sample. Traffic Inj Prev. 2014, 15:S1-S9. 10.1080/15389588.2014.926341

29. Van Eck K, Markle RS, Dattilo L, Flory K: Do peer perceptions mediate the effects of ADHD symptoms and conduct problems on substance use for college students?. Psychol Addict Behav. 2014, 28:431-442. 10.1037/a0036226

30. van Emmerik-van Oortmerssen K, van de Glind G, Koeter MWJ, et al.: Psychiatric comorbidity in treatmentseeking substance use disorder patients with and without attention deficit hyperactivity disorder: results of the IASP study. Addiction. 2014, 109:262-272. 10.1111/add.12370

31. Zulauf CA, Sprich SE, Safren SA, Wilens TE: The complicated relationship between attention deficit/hyperactivity disorder and substance use disorders. Curr Psychiatry Rep. 2014, 16:436. 10.1007/s11920-013-0436-6

32. Pingault JB, Côté SM, Galéra C, Genolini C, Falissard B, Vitaro F, Tremblay RE: Childhood trajectories of inattention, hyperactivity and oppositional behaviors and prediction of substance abuse/dependence: a 15year longitudinal population-based study. Mol Psychiatry. 2013, 18:806-812. 10.1038/mp.2012.87

33. Roberts W, Peters JR, Adams ZW, Lynamc DR, Milich R: Identifying the facets of impulsivity that explain the relation between ADHD symptoms and substance use in a nonclinical sample. Addict Behav. 2014, 39:1272-1277. 10.1016/j.addbeh.2014.04.005

34. Heradstveit O, Skogen JC, Hetland J, Stewart R, Hysing M: Psychiatric diagnoses differ considerably in their associations with alcohol/drug-related problems among adolescents. A Norwegian population-based survey linked with National Patient Registry data. Front Psychol. 2019, 10:1003. 10.3389/fpsyg.2019.01003

35. Ilbegi S, Groenman AP, Schellekens A, et al.: Substance use and nicotine dependence in persistent, remittent, and late-onset ADHD: a 10-year longitudinal study from childhood to young adulthood. J Neurodev Disord. 2018, 10:42. 10.1186/s11689-018-9260-y

36. Jo JM, Won SD: Serial progression from attention-deficit/hyperactivity disorder to alcohol use disorder: serial multiple mediated effects of externalizing disorders and depression. Clin Psychopharmacol Neurosci. 2018, 16:267-275.

37. Jacob L, Haro JM, Koyanagi A: Relationship between attention-deficit hyperactivity disorder symptoms and problem gambling: a mediation analysis of influential factors among 7,403 individuals from the UK. J Behav Addict. 2018, 7:781-791.

38. Romo L, Ladner J, Kotbagi G, Yannick M, Dalia S, Pierre TM, Laurence K: Attention-deficit hyperactivity disorder and addictions (substance and behavioral): prevalence and characteristics in a multicenter study in France. J Behav Addict. 2018, 7:743-751. 10.1556/2006.7.2018.58

39. Du RE, Coleman J, Glanville K, Choi SW, O’Reilly PF, Kuntsi J: Association of polygenic risk for attentiondeficit/hyperactivity disorder with co-occurring traits and disorders. Biol Psychiatry Cogn Neurosci Neuroimaging. 2018, 3:635-643. 10.1016/j.bpsc.2017.11.013

40. Jaisoorya TS, Gowda GS, Nair BS, et al.: Correlates of high-risk and low-risk alcohol use among college students in Kerala, India. J Psychoactive Drugs. 2017, 50:54-61. 10.1080/02791072.2017.1370748

41. Connolly RD, Speed D, Hesson J: Probabilities of ADD/ADHD and related substance use among Canadian adults. J Atten Disord. 2016, 23:1454-1463. 10.1177/1087054716647474

42. Mesman GR: The relation between ADHD symptoms and alcohol use in college students . J Atten Disord. 2015, 19:694-702. 10.1177/1087054713498931

43. Molina BSG, Walther CAP, Cheong JW, Pedersen L, Gnagy EM, Pelham Jr WE: Heavy alcohol use in early adulthood as a function of childhood ADHD: developmentally-specific mediation by social impairment and delinquency. Exp Clin Psychopharmacol. 2014, 22:110-121. 10.1037/a0035656

44. Madsen AG, Dalsgaard S: Prevalence of smoking, alcohol and substance use among adolescents with attention-deficit/hyperactivity disorder in Denmark compared with the general population. Nord J Psychiatry. 2014, 68:53-69. 10.3109/08039488.2013.768293

45. Rashid A, Kuppa A, Kunwar A, Panda D: Thalidomide (5HPP-33) suppresses microtubule dynamics and depolymerizes the microtubule network by binding at the vinblastine binding site on tubulin. Biochemistry. 2015, 54:2149-2159. 10.1021/bi501429j

46. Walther CAP, Cheong JW, Molina BSG, Pelham Jr WE, Wymbs BT, Belendiuk KA, Pedersen SL: Substance use and delinquency among adolescents with childhood ADHD: the protective role of parenting. Psychol Addict Behav. 2012, 26:585-598. 10.1037/a0026818

47. Joshi VV, Patel ND, Rehan M, Kuppa A: Mysterious mechanisms of memory formation: are the answers hidden in synapses?. Cureus. 2019, 11:e5795. 10.7759/cureus.5795

48. Roberts W, Milich R, Fillmore MT: Reduced acute recovery from alcohol impairment in adults with ADHD . Psychopharmacology Berl. 2013, 228:65-74. 10.1007/s00213-013-3016-X

49. Grabemann M, Zimmermann M, Strunz L, et al.: New ways of diagnosing ADHD in adults . Psychiatr Prax. 2017, 44:221-227. 10.1080/15374416.2012.759227 